\title{
Evaluation of Wellness Detection Techniques using Complex Activities Association for Smart Home Ambient
}

\author{
${ }^{1}$ Farhan Sabir Ujager, ${ }^{* 1}$ Azhar Mahmood, ${ }^{2}$ Shaheen Khatoon, ${ }^{1}$ Muhammad Imran, ${ }^{1}$ Umair Abdullah \\ ${ }^{1}$ Department of Computer Science, SZABIST, Islamabad, Pakistan \\ ${ }^{2}$ College of Computer Science, King Faisal University, Al Hassa, Saudi Arabia
}

\begin{abstract}
Wireless Sensor Network based smart homes have the potential to meet the growing challenges of independent living of elderly people in smart homes. However, wellness detection of elderly people in smart homes is still a challenging research domain. Many researchers have proposed several techniques; however, majority of these techniques does not provide a comprehensive solution because complex activities cannot be determined easily and comprehensive wellness is difficult to diagnose. In this study's critical review, it has been observed that strong association lies among the vital wellness determination parameters. In this paper, an association rules based model is proposed for the simple and complex (overlapped) activities recognition and comprehensive wellness detection mechanism after analyzing existing techniques. It considers vital wellness detection parameters (temporal association of sub activity location and sub activity, time gaps between two adjacent activities, temporal association of inter and intra activities). Activity recognition and wellness detection will be performed on the basis of extracted temporal association rules and expert knowledgebase. Learning component is an important module of our proposed model to accommodate the changing trends in the frequent pattern behavior of an elderly person and recommend a caregiver/expert to adjust the expert knowledgebase according to the found abnormalities.
\end{abstract}

Keywords-Wellness detection; Elderly people; WSN Smart homes; Activity recognition

\section{INTRODUCTION}

World population is increasing and according to the World Health Organization (WHO) elderly people population will also increase drastically in the near future [1]. Independent living is a concept that defines a person can live alone without any assistance of any other human being (care giver). Automated mechanisms for the monitoring of an individual are required to ensure the wellness of the elderly person. This monitoring should be accurate, error free and automated (without any human involvement) for an independent livening ambient.

Elderly people have health related issues with the age such as limitations in physical functions, different diseases such as Alzheimer's disease, diabetes, cardio vascular disease. Smart homes technologies have potential to meet the emerging challenges of elderly people independent livings with enhance quality of life.
Wireless sensor network is a vital component of smart home for monitoring of the elderly persons. Variety of sensors deployed all over the house for monitoring purpose such as in electric appliances, gadgets and objects of daily usage for the monitoring of elderly persons as reported in [2].

Activity recognition is one of the active areas of research domain. The aim is to recognize the actions an individual takes to conduct an act of daily living. Most of the researcher have divided these actions into a set of defined activities and termed them "Activities of daily living". This concept was originally proposed in 1950 [3]. There are broadly three categories of activities. These categories are concurrent activities, interleaved and simple atomic activities as reported in [4]. However, most of the literature does not consider all type of activities for their activity recognition and wellness detection of elderly people in smart homes ambient.

Frequent pattern of an individual exists while conducting a specific activity, resulting in sequential frequent pattern as reported $[1,5,6]$. There is a strong association among subactivities and locations where the sub activity is being performed, time duration taken to perform a specific sub activity and specific day of time [7-9]. Wellness detection is determined, when an individual deviates from its sequential frequent pattern among sub activities, individual is not conducting a specific activity on a specific location.

Accurate wellness detection is a challenging research area, several researchers have employed artificial intelligence and machine learning techniques (such as artificial neural networks, support vector machines, Naïve Bayes) as a classifier for the determination of wellness of elderly people in $[9,10]$. Few researchers have also proposed fuzzy rules based classifiers for the activity detection and wellness determination of elderly people in smart home environments [11]. In probabilistic approaches, Markov and Hidden Markov models, where each sub activity is considered as a component of main activity for the activity recognition. Human activities pattern rely on temporal sequence as reported in $[10,12,13]$. Similarly data mining techniques also attracted many researchers to explore for the activity recognition and wellness detection, such as classification techniques, association rule mining techniques and clustering techniques, as reported in $[1,5,10]$. However, wellness detection is a complex research problem; many researchers proposed hybrid models to achieve the said 
objective. There are few hierarchal models proposed for wellness and activity detection [6, 14].

In this paper, we have proposed an association rules based model with the following contribution:

- Temporal association of sub activity and their location

- Time gaps between two adjacent activities consideration

- Temporal association of inter and intra activities

- Learning module

- Recommendations to the caregiver or expert

Rest of the paper is organized as follow: Section II summarizes literature review and highlighting strength and weakness of existing technique by critically analyzing them in tabular formats. In section III a new model is proposed to address the limitation of existing techniques. Finally, paper is concluded and future work is presented in section IV.

\section{RELATED WORK}

Wellness detection is a complex and challenging research domain. Majority of proposed models does not provide a comprehensive solution from different perceptive of wellness and activity detection.

J. Wen., et al [15], proposed a model based on weighted frequent pattern (association mining). The objectives of this model is to find the association rules of activities performed by the elderly person, and build a classifier which is based on these extracted association rules. However, time series analysis of activities with the location of activities is not considered. M.T Moutacalli., et al [5], have employed frequent pattern mining for the determination of activity recognition and wellness detection. In proposed model, association mining is performed for extraction of homogenous frequent pattern activity model. The strength of this work is that this model considers event duration and time gap between adjacent activities. However, this model cannot recognize complex activities. S.T.Bourobou., et al [10] proposed a hybrid model based of association mining and AAN. The proposed model consists of two steps of repeated activity discovery by using FP growth algorithm and clustered these patterns into activities using K-pattern algorithm. ANN based classifier is used for the classification of the activities. However, integration of multiple techniques into a single model makes the whole process difficult and complex to implement. L.G. Fahad., et al [6] proposed a hybrid hierarchal model based on frequent patterns and probabilistic approach to find the activity tasks. Frequent pattern mining is being conducted to extract the inhabitant behavior pattern. However, it is a tedious task to create routine tasks lists manually. This model does not follow temporal analysis for wellness determination. S.Nasreen., et al [16], a hybrid model is proposed based on Association rules for inhabitant pattern. These association rules are used for the assignment of activity category when new activity arrives as an input. Binary support vector machine is used to detect correct or incorrect assignment. However, inter and intra relationship of activities has not been considered. L.G. J. Saives., et al [17] have proposed a hybrid model based on association rule mining and extended finite automata for the mapping of activities found from the association rule mining. However, prior knowledge is required and temporal deviations are not considered for wellness detection. Similarly repeated activities might not represent the same sequence of events.

A. Forkan., et al [11] proposed a probabilistic model to detect the abnormality in the activity build model, to identify the wellness of an elderly person. Hidden Markov Model (HMM) is used for the change detection in the activities of daily living along with identification of change in daily routine using statistical history and expert knowledgebase for abnormality detection. This model does not follow single wellness detection criteria which is the major contribution of this study. The outcome of each module is then serves as an input to fuzzy rules based classifier for the classification of activities and detection of abnormality. However, this model might have less acceptability for elderly as wearable sensors must be used for expert knowledgebase. Similarly, different modules working together making the process complex and prior knowledge is required as a statistical histories for the prediction and abnormality detection. Similarly N.K. Suryadevara [8], proposed another probabilistic model is for the prediction wellness in the smart home environment based on appliance usage. Two wellness functions been used. Irregular patterns will lead to the abnormality which helps to identify whether an elderly person is well or unwell. However, activities are presented in simple manner and appliance usage monitoring might not be suitable when the person is not using any specific appliance. F.Ordonez., et al [2], proposed a hybrid model which is based on training phase and classification phase. For temporal and sequential activities analysis Hidden Markov model is used. The objective of this study is to validate hybrid model performs better than single technique based model. It used Hidden Markov Model for training and for classification phase SVM reported better results. However, while validating the results for temporal and sequential activities, other sequential and association mining techniques were not considered. L.Kalra., et al [13], proposed two stage probabilistic model based on Markov model. The proposed model process the sensor data in two stages, in the first stage sensor data is analyzed for the patterns of activity events by using Markov Model. However, time gap between adjacent activities are not considered for the determination of wellness of elderly person. K. Gayathri., et al [14] proposed a probabilistic hierarchal model for abnormality detection to determine the wellness. This model combines the data and knowledge driven parameters by employing Markov logic networks for abnormality detection. This model considers location, object usage, time of usage for the abnormality detection. However, manual rules based systems requires effort to create knowledgebase. Sensor and data relationship is ignored.

E. Kim., et al [4] have discussed the uncertainty parameters in the wellness determination. This study serves as groundwork to develop diagnostic system. In [7], tree based regression algorithm is being proposed for the classification of activities in the training phase and in the later phase when new activity can be predicted as future activity. However, this model does not consider complex activities. 
E. Nazerfard., et al [9] proposed an activity classification model based on Bayesian network. This proposed model proposes two steps of inference for the prediction of upcoming activity and its label. This model considers time analysis and activity features. However, complex activities are not considered for the prediction.

X. Hong., et al [18] proposed model based on time segmentation. The model extracts events that are associated with a complete activity. The first segmentation is location based, second segmentation is model-based, and third is based on modeling of each activity in terms of sensor activation to determine. The third proposed algorithm identifies the most predominate sensor in the activity to identify the event which that sensor exhibits. However in this approach, rules need to be defined manually for the activity discovery.

\section{A. Critical Evaluation}

In this sub section of literature review, critical evaluation is being conducted. Fifteen papers are represented in three different tables for the cumulative review of each literature under the set of predefined vital parameters.

Table.I represents the methodology of the proposed techniques for wellness and activity detection for smart home. Majority of the existing techniques aimed to extract elderly persons frequent behavior patterns, whether they have employed Hidden Markov model [2, 9, 10], [7] tree based regression analysis association rules or frequent pattern mining $[5,6,15,16]$ and deviation from this pattern leads to the abnormality. A proven technique should be employed for the extraction of frequent patterns of an elderly person, like frequent pattern or association mining.

Table.II represents the implementation details of existing techniques which helps to explain the implementation details, environment and validation. Majority of the proposed models have not validated and compared their results with the existing models and methods.

Table.III represents the vital parameters which are necessary for the wellness detection. These parameters have strong impact of elderly person's activities and wellness detection. In table.III, type of the activities which different proposed models have used in activity detection, similarly the association of intra and inter activities is necessary to understand pattern of elderly person behaviors. Time gap between adjacent activities is important criteria to measure the wellness of elderly person. Association of time with location is a necessary parameter to understand pattern where an individual will perform a specific activity. Temporal analysis is important criteria to understand the elderly person is also one of the most vital criteria to understand elderly person activity pattern.

\section{PROPOSED MODEL}

In this section, a model is proposed for the wellness detection based on association rules mining and frequent patterns of the behavior of the elderly people. From the critical evaluation section it is evident that association exists among different parameters of activity recognition and wellness detection. Association rules between sub activities and location of sub activities have been extracted from the sensor data, correlation among sub activities for as inter temporal association among sub activities rules are extracted and time gap between adjacent activities have proposed to be found to determine the wellness of elderly people. Model is proposed by considering all those parameter which were mainly ignored in existing literature such as detection of overlapped activities; location based association, intra and inters activities associations.

The proposed model consists of 9 modules, namely, data transformation module, sub activity (location and time) correlation module, time gap between two adjacent activities module, sub activity (sequence of sub activities and time) correlation module, sub activity (location and sequence of activities) correlation w.r.t time module, expert knowledgebase module, contextual database module, learning component and activity recognition module as shown in the Fig.1.

\section{A. Data Transformation module}

In smart home data is generated from the WSN's network. To make the sensor data suitable for processing, sensor data is transformed with labels (for example, if a person is sleeping, bed sensor is active, the activity will be marked as 'sleeping', time duration of this active sensor will be the duration of the activity and location of the sensor will be the location of activity). For example, an elderly person of a smart home wants to make coffee, he/she will achieve the said task in a series of sub activities for example: 1. Staring of stove, 2. Filling the pan with water, 3. Opening coffee jar and 4. Mixing coffee \& water etc.

These steps are considered as sub activities and while making of coffee are considered as an activity. Similarly it is also important to consider time gap between two adjacent sub activities for the determination of wellness of an elderly person.

\section{B. Temporal Association of sub activity's location and sub activities}

For activity recognition and wellness detection it is important to determine and extract the association of each sub activity time duration with the location where that sub activity has been performed along with the day of time. Most frequent association rules are extracted by using FP-Growth. For example, the normal pattern of an individual sleeping routine at around $2200 \mathrm{hrs}$ in 'bedroom' for approximately 8 hours. If a person is in 'dining room' at around $2200 \mathrm{hrs}$ and duration of the activity is more than it should spend in the 'dining room' so the violation of rule will indicate that person is not well.

\section{Sub activity (sequence of sub activities and time) correlation module:}

For activity recognition the correlation of sequence of sub activities with their time duration is required to handle complex activities. As discussed earlier an activity consists of sequence of sub activities. An example is discussed earlier of coffee making. The correlation among the sub activities and time in $24 \mathrm{hrs}$ is determined by using Generalized Sequential Pattern mining (GSP) [19].The outcome of this process will be association rules (correlation among sub activities and time). 


\section{Time gap determination of two adjacent activities over a specific time:}

The input of this process is sub activities labels and time duration to perform each sub activity to determine the time gap between two adjacent sub activities over a specific day of time. The benefit of this outcome is the determination of the wellness of an elderly person most of the literature surveyed has ignored this important wellness parameter. For example, a healthy person will perform sub activities in normal routine with a normal time gap between two adjacent activities, while an unhealthy elderly person might not execute the sub activities with the normal time gap.

\section{E. Sub activity (location, time gap and sequence of activities) correlation w.r.t time module:}

This module servers as global perceptive of activity, in this module activities rules are formulated from vital parameters of complete activity detection rules. In this module association rules of (location + time duration), association rules of sub activities and time gap between adjacent sub activities with respect to time of day respectively are correlated using association rule mining (using FP- Growth) to extract pattern of these vital parameter over a specific time of day. The outcome of this module will be association rules of the required parameters (location, time gap and sequence of sub activities) over a specific time of day to accurately determine the wellness of an elderly person. For example, a healthy person has a routine to wake up (S1) around (0700 - 0715hrs).

(T) in (location = bed room) $(\mathrm{L} 1)$, time gap from bed to washroom(L2) (45- 50s)(G1) and to the washroom (use of toilet (2 mins)(S2), use of tap (3 mins) (S3) time duration between these two adjacent activities is usually (30-45s) (G2) and then go the kitchen. In this brief example, the generated rule:

\section{$(S 1, S 2, S 3) \wedge(L 1, L 2, L 3) \wedge(G 1, G 2, G 3) \wedge T \rightarrow$ Activity}

For overlapped activities, a set of rules have same location and temporal association (location of sub activities and time of day) but different sequence of sub activities and different time duration between adjacent activities.

\section{F. Expert (medical) knowledgebase:}

This module will have hard rules for an individual from medical history perspective. This rules are the recommendation for an individual like walk time, sleep time (recommended).

\section{G. Database module}

In this module association rules which are extracted from above mentioned model will be saved in this module. Expert (medical) knowledgebase rules will also be saved. This module will serve as a rules repository for the online activity recognition module.

\section{H. Learning module:}

The learning module updates the existing set of rules by monitoring the sensor data streams and extracting the contextual spatial-temporal association of the changing trends in the behavior pattern of an elderly person. The learning component also monitors of the outcome of the online activity recognition and wellness detection module, on correct diagnoses the weight of the rule will increase and will have high priority. Similarly to accommodate the changing trends in the behavior pattern, rules will be updated in the database repository.

The second novel function of the learning module is to recommend the caregiver the abnormalities found in the inhabitant behavior to make necessary changes in the expert knowledgebase according to the recommendation.

\section{Online activity recognition and wellness detection module:}

In this module have the association rules generated and the hard rules of expert knowledge base will be mapped with sensor data. Data from the sensor network is coming to this module and data is being compared with knowledge base and association rules. If the rules are met for the input data the activities are considered normal and the elderly person is considered well. Incase rules are violated the elderly person is considered unwell. 


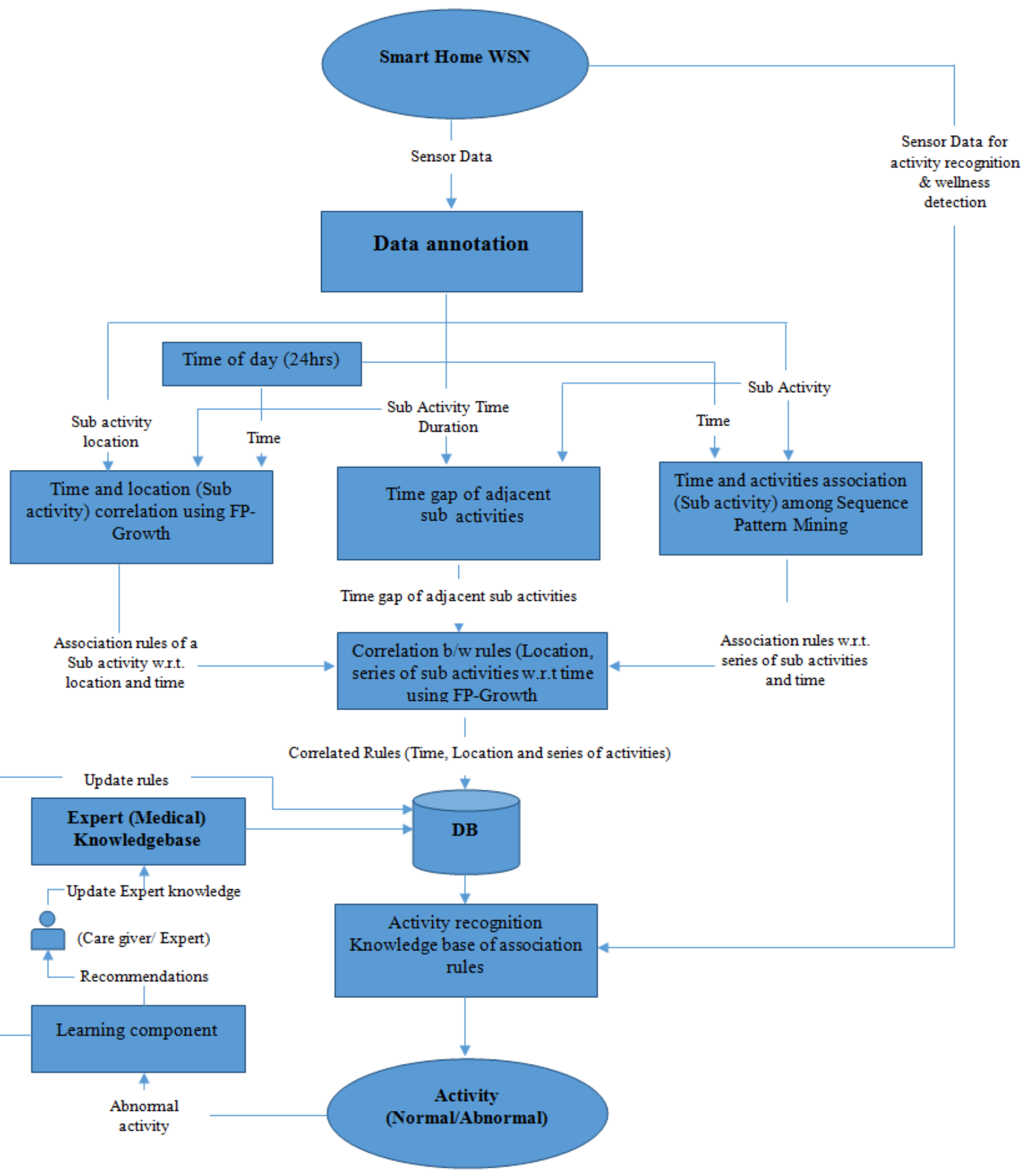

Fig. 1. Proposed Model View 
TABLE I. CRITICAL EVALUATION OF RELATED WORK

\begin{tabular}{|c|c|c|c|c|c|c|c|}
\hline $\begin{array}{l}R \\
\text { ef }\end{array}$ & $\begin{array}{l}\text { Wellness } \\
\text { determinati } \\
\text { on Criteria }\end{array}$ & $\begin{array}{l}\text { Approach } \backslash \text { Algor } \\
\text { ithm }\end{array}$ & Study Characteristics & Main Outcomes & Strengths & Limitations & Suggestions \\
\hline $\begin{array}{l}{[1} \\
5]\end{array}$ & $\begin{array}{l}\text { Detecting } \\
\text { ADL } \\
\text { activities }\end{array}$ & $\begin{array}{l}\text {-Association } \\
\text { rules btw } \\
\text { activities } \\
\text {-Build activity } \\
\text { classifier over } \\
\text { association rules } \\
\text {-Classification } \\
\text { of overlapped } \\
\text { activities }\end{array}$ & $\begin{array}{l}\text { Identification of } \\
\text { frequent patterns based } \\
\text { on Association rules. }\end{array}$ & $\begin{array}{l}\text { - Use of global weight } \\
\text { \&local weight of the sensor } \\
\text { events to differentiate the } \\
\text { activities for overlapped } \\
\text { activities. } \\
\text {-The activities that have } \\
\text { overlapped frequent } \\
\text { patterns or even share the } \\
\text { same frequent patterns can } \\
\text { still be differentiated }\end{array}$ & $\begin{array}{l}\text { - Overlapped ADLs } \\
\text { are considered. } \\
\text { - Results validated } \\
\text { \&Compared with } \\
\text { existing techniques } \\
\text { such as Decision } \\
\text { Tree, Naïve } \\
\text { Bayesian \&HMM }\end{array}$ & $\begin{array}{l}\text { - Hidden } \\
\text { variables (such } \\
\text { as interleaved } \\
\text { activities )of } \\
\text { ADLs are } \\
\text { ignored } \\
\text {-Time series } \\
\text { analysis } \\
\text { missing } \\
\text { - Unable to } \\
\text { detect complex } \\
\text { activities }\end{array}$ & $\begin{array}{l}\text { Association rules } \\
\text { integration with } \\
\text { HMM may produce } \\
\text { better results in } \\
\text { activity recognition. } \\
\text { Fuzzy rules based } \\
\text { classifier along with } \\
\text { temporal mining } \\
\text { helpful in } \\
\text { determining complex } \\
\text { activity recognition. }\end{array}$ \\
\hline $\begin{array}{l}{[5} \\
]\end{array}$ & $\begin{array}{l}\text { Detecting } \\
\text { ADL } \\
\text { activities } \\
\text { (Alzheimer' } \\
\text { s disease) }\end{array}$ & $\begin{array}{l}\text {-Frequent } \\
\text { pattern Mining } \\
\text { (time series } \\
\text { analysis) } \\
\text {-Wellness } \\
\text { functions } \\
\text {-Classification }\end{array}$ & $\begin{array}{l}\text { (1) Transforming the } \\
\text { temporal Db to non- } \\
\text { temporal (2) Finding } \\
\text { homogenous } \\
\text { subsequence activities } \\
\text { (3) Activity model: } \\
\text { Classification of } \\
\text { activities }\end{array}$ & $\begin{array}{l}\text {-Present the various stages } \\
\text { of Technological assistance } \\
\text { \&propose a new algorithm } \\
\text { for the step of activities } \\
\text { models detection }\end{array}$ & $\begin{array}{l}\text {-Test bed } \\
\text { implementation } \\
\text {-Each concept is } \\
\text { properly defined }\end{array}$ & $\begin{array}{l}\text { - Activity time } \\
\text { gap } \\
\text { - Results are } \\
\text { not compared } \\
\text { \&validated. } \\
\text { - Dataset is not } \\
\text { being discussed }\end{array}$ & $\begin{array}{l}\text { Association rule } \\
\text { mining along with the } \\
\text { time series analysis } \\
\text { should be considered } \\
\text { while keep the event } \\
\text { duration \&gap among } \\
\text { events. }\end{array}$ \\
\hline $\begin{array}{l}{[1} \\
1]\end{array}$ & $\begin{array}{l}\text { Detecting } \\
\text { abnormaliti } \\
\text { es in ADLs }\end{array}$ & $\begin{array}{l}\text {-Hidden } \\
\text { Markov Model } \\
\text {-Statistical } \\
\text { estimations } \\
\text { (Mean } \\
\text { \&standard } \\
\text { deviations) } \\
\text { - Fuzzy rule } \\
\text { classifier }\end{array}$ & $\begin{array}{l}\text { Learning techniques } \\
\text { for predicting } \\
\text { abnormalities } \\
\text { \&behavioral trends } \\
\text { Hidden Markov Model } \\
\text { based approach for } \\
\text { detecting abnormalities } \\
\text { (trained by Machine } \\
\text { learning techniques) } \\
\text { Fuzzy rule-based } \\
\text { model for making the } \\
\text { final guess }\end{array}$ & $\begin{array}{l}\text {-HMM used to detect the } \\
\text { anomalies in the ADLs } \\
\text {-Fuzzy rule-based system } \\
\text { gives output as weather the } \\
\text { anomaly is true. }\end{array}$ & $\begin{array}{l}\text { - Comprehensive } \\
\text { ADLs monitoring } \\
\text { - Different medical } \\
\text { aspects are } \\
\text { considering along } \\
\text { ADLs }\end{array}$ & $\begin{array}{l}\text { - Fuzzy rules } \\
\text { are generated } \\
\text { manually } \\
\text {-Target user } \\
\text { with many } \\
\text { wearable } \\
\text { sensors which } \\
\text { periodically } \\
\text { send different } \\
\text { vital signs data } \\
\text { of the user } \\
\text {-Model is } \\
\text { expensive \& } \\
\text { complex }\end{array}$ & $\begin{array}{l}\text { Self-generated } \\
\text { association fuzzy rule } \\
\text { system can be a major } \\
\text { improvement }\end{array}$ \\
\hline $\begin{array}{l}{[4} \\
]\end{array}$ & $\begin{array}{l}\text { Identificatio } \\
\mathrm{n} \text { of activity } \\
\text { recognition } \\
\text { parameters } \\
\text { \&their } \\
\text { impact of } \\
\text { accuracy }\end{array}$ & $\begin{array}{l}\text {-Fault tree } \\
\text { analysis (FTA) }\end{array}$ & $\begin{array}{l}\text { Uncertainty parameters } \\
\text { \&measures are } \\
\text { discussed. Different } \\
\text { models are taken into } \\
\text { consideration TAM, } \\
\text { GAM \&SGAM for the } \\
\text { analysis. }\end{array}$ & $\begin{array}{l}\text { - Diagnostic accuracy } \\
\text { measures of AR systems } \\
\text { capable of pinpointing the } \\
\text { sources of accuracy loss }\end{array}$ & $\begin{array}{l}\text { - Introduced a } \\
\text { method for } \\
\text { uncertainty impact } \\
\text { analysis, which for a } \\
\text { given AR system, } \\
\text { measures the impact } \\
\text { of each uncertainty } \\
\text { source on AR } \\
\text { performance }\end{array}$ & $\begin{array}{l}\text { Different } \\
\text { datasets should } \\
\text { be used for } \\
\text { analysis } \\
\text { Hybrid models } \\
\text { are not } \\
\text { considered for } \\
\text { the analysis }\end{array}$ & $\begin{array}{l}\text { Different datasets } \\
\text { should have been } \\
\text { used for the } \\
\text { evaluation of } \\
\text { identified measures } \\
\text { \&hybrid models are } \\
\text { ignored while } \\
\text { evaluating. }\end{array}$ \\
\hline $\begin{array}{l}{[7} \\
]\end{array}$ & $\begin{array}{l}\text { Activity } \\
\text { forecasting } \\
\text { \&predicting } \\
\text { the } \\
\text { occurrence } \\
\text { of future } \\
\text { activities }\end{array}$ & $\begin{array}{l}\text {-Regression- } \\
\text { tree-based } \\
\text { (Machine } \\
\text { Learning } \\
\text { technique) }\end{array}$ & $\begin{array}{l}\text { Algorithm extracts } \\
\text { high-level features } \\
\text { from sensor events } \\
\text { \&inputs these features } \\
\text { to a machine learning } \\
\text { algorithm which } \\
\text { forecasts when a target } \\
\text { activity will next occur }\end{array}$ & $\begin{array}{l}\text {-The proposed algorithm } \\
\text { does not rely on a separate } \\
\text { AR component, but rather } \\
\text { derives feature attributes } \\
\text { directly from sensor event } \\
\text { data within the smart } \\
\text { home }\end{array}$ & $\begin{array}{l}\text { Well defined time } \\
\text { boundaries of the } \\
\text { activities \&gap } \\
\text { between activities } \\
\text { are important to } \\
\text { discover }\end{array}$ & $\begin{array}{l}\text { - Complex } \\
\text { ADLs are not } \\
\text { considered } \\
\text {-Activities time } \\
\text { boundaries } \\
\text {-Complex } \\
\text { activities not } \\
\text { considered }\end{array}$ & $\begin{array}{l}\text { Hybrid approach, } \\
\text { especially for the data } \\
\text { preparation for the } \\
\text { classifier \&for the } \\
\text { consideration of } \\
\text { temporal element. }\end{array}$ \\
\hline $\begin{array}{l}{[8} \\
]\end{array}$ & $\begin{array}{l}\text { Abnormalit } \\
\mathrm{y} \\
\text { identificatio } \\
\mathrm{n}\end{array}$ & $\begin{array}{l}\text {-Activity } \\
\text { annotated via } \\
\text { conditional } \\
\text { probability } \\
\text { method } \\
\text {-Probabilistic } \\
\text { method } \\
\text { wellness } \\
\text { determination }\end{array}$ & $\begin{array}{l}\text { Behavior detection } \\
\text { process based on the } \\
\text { observed sensor data in } \\
\text { performing essential } \\
\text { daily activities }\end{array}$ & $\begin{array}{l}\text {-A proposed framework to } \\
\text { verifies the behavior of } \\
\text { elderly at three different } \\
\text { stages of daily living } \\
\text { (usage of appliances, } \\
\text { activity recognition } \\
\text { \&forecast levels) }\end{array}$ & $\begin{array}{l}\text {-Trivial process } \\
\text {-Experimental details } \\
\text { are clear } \\
\text {-Experimentation are } \\
\text { conducted on five } \\
\text { different dataset for } \\
\text { validation } \\
\text {-Prototype is } \\
\text { developed }\end{array}$ & $\begin{array}{l}\text {-Prior } \\
\text { knowledge is } \\
\text { required } \\
\text {-Activities } \\
\text { boundaries } \\
\text { undefined } \\
\text { - Energy } \\
\text { inefficient } \\
\text { - Simple } \\
\text { activities }\end{array}$ & $\begin{array}{l}\text { For efficient training } \\
\text { period fixed rules } \\
\text { \&training should be } \\
\text { implemented side by } \\
\text { side \&remove fixed } \\
\text { rules by their } \\
\text { application in the } \\
\text { process. }\end{array}$ \\
\hline $\begin{array}{l}{[9} \\
]\end{array}$ & $\begin{array}{l}\text { Predicting } \\
\text { future } \\
\text { ADLs }\end{array}$ & $\begin{array}{l}\text { - Bayesian } \\
\text { network }\end{array}$ & $\begin{array}{l}\text { An activity prediction } \\
\text { model using Bayesian } \\
\text { networks together with } \\
\text { a novel two-step }\end{array}$ & $\begin{array}{l}\text { - Predicting the start time } \\
\text { of next activity } \\
\text {-Activity label prediction } \\
\text { based on features }\end{array}$ & $\begin{array}{l}\text {-Physical } \\
\text { implementation } \\
\text {-Tested on three } \\
\text { different elderly }\end{array}$ & $\begin{array}{l}\text {-Prior } \\
\text { knowledge is } \\
\text { required } \\
\text {-Different types }\end{array}$ & $\begin{array}{l}\text { Association between } \\
\text { sequences are } \\
\text { necessary to find } \\
\text { complex ADLs along }\end{array}$ \\
\hline
\end{tabular}




\begin{tabular}{|c|c|c|c|c|c|c|c|}
\hline & & & $\begin{array}{l}\text { inference process to } \\
\text { predict both the next } \\
\text { activity features \&the } \\
\text { next activity label }\end{array}$ & & $\begin{array}{l}\text { people } \\
\text {-Results validated } \\
\text { against existing } \\
\text { approaches }\end{array}$ & $\begin{array}{l}\text { of ADLs are } \\
\text { not considered. }\end{array}$ & $\begin{array}{l}\text { statistical methods } \\
\text { such as Hidden } \\
\text { Markov Method } \\
\text { (HMM) is helpful in } \\
\text { finding the hidden } \\
\text { variables }\end{array}$ \\
\hline $\begin{array}{l}{[\mathbf{1}} \\
\mathbf{0}]\end{array}$ & $\begin{array}{l}\text { User } \\
\text { activity } \\
\text { detection }\end{array}$ & $\begin{array}{l}\text {-Pattern } \\
\text { Clustering (K- } \\
\text { Pattern } \\
\text { clustering algo) } \\
\text { along frequent } \\
\text { pattern by FP } \\
\text { growth } \\
\text { \&activity } \\
\text { decision (ANN) }\end{array}$ & $\begin{array}{l}\text { 1. Frequent pattern are } \\
\text { extracted using FP } \\
\text { growth } 2 \text {. Frequent } \\
\text { pattern are clustered by } \\
\text { using K-Pattern algo } \\
\text { (for overlapping } \\
\text { patterns in multiple } \\
\text { clusters) } \\
\text { 3. ANN for } \\
\text { classification }\end{array}$ & $\begin{array}{l}\text {-Activity recognition } \\
\text {-Noisy data handling in } \\
\text { datasets }\end{array}$ & $\begin{array}{l}\text {-Considering both } \\
\text { concepts of activity } \\
\text { clustering \&activity } \\
\text { decisions }\end{array}$ & $\begin{array}{l}\text { - For Learning } \\
\text { part (ANN) } \\
\text { will be } \\
\text { expensive } \\
\text { - Expensive } \\
\text { processing as } \\
\text { integrating } \\
\text { multiple } \\
\text { techniques } \\
\text { together }\end{array}$ & $\begin{array}{l}\text { To reduce the } \\
\text { complexity, efficient } \\
\text { classifiers can be } \\
\text { used }\end{array}$ \\
\hline $\begin{array}{l}{[2} \\
]\end{array}$ & $\begin{array}{l}\text { Detecting } \\
\text { ADLs }\end{array}$ & $\begin{array}{l}\text {-Recognition of } \\
\text { ADLs by using } \\
\text { Hybrid } \\
\text { approach } \\
\text {-HMM is used } \\
\text { as trainer of } \\
\text { different ML } \\
\text { techniques }\end{array}$ & $\begin{array}{l}\text { HMM is used for } \\
\text { dealing with temporal } \\
\text { characteristics of } \\
\text { sequential data. HMM } \\
\text { is trained with the } \\
\text { probabilistic classifier } \\
\text { which is able to predict } \\
\text { the given sample as a } \\
\text { classifier }\end{array}$ & $\begin{array}{l}\text {-Recognition of ADLs by } \\
\text { using Hybrid approach } \\
\text {-Hidden Markov model is } \\
\text { hybrid \&tested with } \\
\text { different machine learning } \\
\text { techniques }\end{array}$ & $\begin{array}{l}\text {-Discussed in detail } \\
\text { on ANN \&SVM. } \\
\text {-Raw data is } \\
\text { represented in Raw, } \\
\text { Change point, Last } \\
\text { Sensor } \\
\text {-Results validated } \\
\text { with five different } \\
\text { models }\end{array}$ & $\begin{array}{l}\text { Prior expert } \\
\text { knowledge is } \\
\text { required for the } \\
\text { system at the } \\
\text { initial stage. }\end{array}$ & $\begin{array}{l}\text { For efficient training } \\
\text { period fixed rules } \\
\text { \&training should be } \\
\text { implemented side by } \\
\text { side \&remove fixed } \\
\text { rules by their } \\
\text { application in the } \\
\text { process }\end{array}$ \\
\hline $\begin{array}{l}{[1} \\
3]\end{array}$ & $\begin{array}{l}\text { Detecting } \\
\text { ADLs }\end{array}$ & $\begin{array}{l}\text { - Markov Model } \\
\text { - Hidden } \\
\text { Markov Model }\end{array}$ & $\begin{array}{l}\text { This study deals with } \\
\text { learning user's daily } \\
\text { behaviorby markov } \\
\text { model; } \\
\text { it applies markov } \\
\text { model in two level to } \\
\text { first learn user's habits } \\
\text { \&then correctany } \\
\text { misclassification of } \\
\text { activity. }\end{array}$ & $\begin{array}{l}\text { - To model each activity } \\
\text { separately where sensors } \\
\text { correspond to states } \\
\text { (Markov Model) } \\
\text { - To enhance accuracy } \\
\text { \&find inter-activity } \\
\text { transition wrt time- } \\
\text { dependent relationships } \\
\text { between two contiguous } \\
\text { activities (Hidden Markov } \\
\text { Model) }\end{array}$ & $\begin{array}{l}\text { - Temporal } \\
\text { associations of } \\
\text { ADLS are } \\
\text { considered } \\
\text { - Use of concurrent } \\
\text { active sensors to } \\
\text { train the activity } \\
\text { model by } \\
\text { considering sensor } \\
\text { activations as the } \\
\text { states for that model. } \\
\text { - Evaluation perform } \\
\text { over multiple } \\
\text { datasets }\end{array}$ & $\begin{array}{l}\text {-Time gap } \\
\text { between two } \\
\text { activities are } \\
\text { not considered. } \\
\text {-Different } \\
\text { medical aspects } \\
\text { are missing } \\
\text {-Overlapped } \\
\text { activities are } \\
\text { not considered }\end{array}$ & $\begin{array}{l}\text { Association rule } \\
\text { mining can be helpful } \\
\text { for finding the inter } \\
\text { activities temporal } \\
\text { association along } \\
\text { HMM. }\end{array}$ \\
\hline $\begin{array}{l}{[1} \\
8]\end{array}$ & $\begin{array}{l}\text { ADLs } \\
\text { Detection }\end{array}$ & $\begin{array}{l}\text { Evidential } \\
\text { Activity } \\
\text { Monitoring } \\
\text { (Evidence } \\
\text { Theory) }\end{array}$ & $\begin{array}{l}\text { The architecture } \\
\text { consists } \\
\text { of two main processes, } \\
\text { the detection process } \\
\& \text { the recognition } \\
\text { process }\end{array}$ & $\begin{array}{l}\text {-The detection process is } \\
\text { responsible for the } \\
\text { segmentation of sensor } \\
\text { streams to detect activity } \\
\text { occurrences (Evidence) } \\
\text { - The segmented sensor } \\
\text { streams are then used as } \\
\text { inputs to the recognition } \\
\text { process }\end{array}$ & $\begin{array}{l}\text {-Sensor data as an } \\
\text { evidence for an } \\
\text { activity monitoring } \\
\text {-Time series segment } \\
\text { correlation with a } \\
\text { complete activity } \\
\text {-Considering } \\
\text { correlations of } \\
\text { locations, objects } \\
\text { \&sensors }\end{array}$ & $\begin{array}{l}\text {-Single } \\
\text { occupancy } \\
\text { environment } \\
\text { - Simple } \\
\text { activities } \\
\text {-The current } \\
\text { study focuses } \\
\text { only on the } \\
\text { environmental } \\
\text { activities }\end{array}$ & $\begin{array}{l}\text { Correlations of } \\
\text { locations, objects } \\
\text { \&sensors with } \\
\text { activities can be } \\
\text { found out using } \\
\text { association rules } \\
\text { \&later used as } \\
\text { evidence for } \\
\text { evidential ontology } \\
\text { network of activity }\end{array}$ \\
\hline $\begin{array}{l}{[1} \\
7]\end{array}$ & $\begin{array}{l}\text { Detecting } \\
\text { ADLs }\end{array}$ & $\begin{array}{l}\text { Sequence } \\
\text { pattern mining, } \\
\text { Aprori Algo } \\
\text { (discovery of } \\
\text { habits) } \\
\text { Extended Finite } \\
\text { Automata (Map } \\
\text { event to an } \\
\text { activity model) }\end{array}$ & $\begin{array}{l}\text { The proposed } \\
\text { approach is used for } \\
\text { over watching the } \\
\text { disease evolution that } \\
\text { can be characterized } \\
\text { by behavior changes, } \\
\text { to be helped by } \\
\text { detecting the activities } \\
\text { the inhabitant } \\
\text { performs. }\end{array}$ & $\begin{array}{l}\text { - Activity recognition by } \\
\text { sequence pattern mining } \\
\text { - Activity model by EFA } \\
\text { - A method to build a } \\
\text { model representing } \\
\text { recommendations from the } \\
\text { medical staff, so that the } \\
\text { recognized activities } \\
\text { \&behavior deviations of } \\
\text { the inhabitant can be } \\
\text { detected }\end{array}$ & $\begin{array}{l}\text {-Claims to have no } \\
\text { prior knowledge for } \\
\text { activity discovery } \\
\text {-Real time activity } \\
\text { recognition } \\
\text {-Case studies } \\
\text { discussion w.r.t to } \\
\text { proposed approach }\end{array}$ & $\begin{array}{l}\text {-No temporal } \\
\text { deviations } \\
\text {-Repeated } \\
\text { activities might } \\
\text { not be } \\
\text { presented by } \\
\text { the same series } \\
\text { of events } \\
\text {-Healthcare } \\
\text { contextual } \\
\text { features }\end{array}$ & $\begin{array}{l}\text { Time series analysis } \\
\text { along with the } \\
\text { proposed solution } \\
\text { might give better } \\
\text { results \&association } \\
\text { among sub activities } \\
\text { consideration will } \\
\text { help in better activity } \\
\text { recognition }\end{array}$ \\
\hline $\begin{array}{l}{[1} \\
4]\end{array}$ & $\begin{array}{l}\text { Detecting } \\
\text { ADLs }\end{array}$ & $\begin{array}{l}\text { Markov Logic } \\
\text { Network (MLN) } \\
\text { (Discovery of } \\
\text { Activity } \\
\text { \&abnormality } \\
\text { detection ) }\end{array}$ & $\begin{array}{l}\text { Hierarchical activity } \\
\text { recognition concept, } \\
\text { any abnormality in the } \\
\text { occupant's activity is } \\
\text { recognized \&decision } \\
\text { is at each layer. } \\
\text { Factors (objects, time, } \\
\text { location \&duration of } \\
\text { activity) }\end{array}$ & $\begin{array}{l}\text {-Use a hierarchical } \\
\text { approach to detect } \\
\text { abnormality in occupant } \\
\text { behavior } \\
\text {-Identification of factors } \\
\text { associated with the activity } \\
\text { such as objects, location, } \\
\text { time \&duration } \\
\text {-Knowledgebase consist of }\end{array}$ & $\begin{array}{l}\text {-Hybrid approach } \\
\text { (spatio-temporal } \\
\text { \&context-based } \\
\text { reasoning) } \\
\text {-Distributed decision } \\
\text { making } \\
\text {-Concurrent } \\
\text { activities } \\
\text { consideration } \\
\end{array}$ & $\begin{array}{l}\text {-Self- } \\
\text { generation of } \\
\text { knowledgebase } \\
\text { for activity } \\
\text { recognition } \\
\text {-No Sensor } \\
\text { data } \\
\text { relationships } \\
\text { - Simple } \\
\end{array}$ & $\begin{array}{l}\text { In hierarchal model if } \\
\text { at each level the best } \\
\text { approach with respect } \\
\text { to the factor is } \\
\text { applied could yield } \\
\text { better results. Fuzzy } \\
\text { association rules } \\
\text { generation could be } \\
\text { helpful for automated }\end{array}$ \\
\hline
\end{tabular}




\begin{tabular}{|c|c|c|c|c|c|c|c|}
\hline & & & & $\begin{array}{l}\text { hard \&soft rules for } \\
\text { activity recognition }\end{array}$ & $\begin{array}{l}\text {-Quick decision } \\
\text { response }\end{array}$ & $\begin{array}{l}\text { activities } \\
\text {-Time gaps not } \\
\text { considered }\end{array}$ & rules generation \\
\hline $\begin{array}{l}{[6} \\
]\end{array}$ & $\begin{array}{l}\text { Abnormalit } \\
\text { y detection } \\
\text { in ADLs }\end{array}$ & $\begin{array}{l}\text { Finding activity } \\
\text { patterns using } \\
\text { Frequent pattern } \\
\text { Mining, tasks } \\
\text { set by } \\
\text { conditional } \\
\text { probabilities } \\
\& \text { Self defined } \\
\text { rules to find } \\
\text { abnormalities }\end{array}$ & $\begin{array}{l}\text { Pattern mining } \\
\text { algorithm to detect } \\
\text { theabnormality in } \\
\text { inhabitant behaviors. } \\
\text { System learns \&update } \\
\text { from new stream. } \\
\text { GATS algorithm } \\
\text { compute } \\
\text { tasksequences. Tasks } \\
\text { used for activity } \\
\text { recognition }\end{array}$ & $\begin{array}{l}\text { - Activities Pattern } \\
\text { - Activities Tasks } \\
\text { - Activities Recognitions } \\
\text { \&abnormality detection }\end{array}$ & $\begin{array}{l}\text { - Hierarchal structure } \\
\text {-Activities \&sub } \\
\text { activities are } \\
\text { considered } \\
\text {-Quick decision } \\
\text { response }\end{array}$ & $\begin{array}{l}\text {-Hierarchal } \\
\text { structures are } \\
\text { complex } \\
\text {-Self- } \\
\text { generation of } \\
\text { routine plans } \\
\text { - Temporal } \\
\text { analysis needs } \\
\text { to be done } \\
\text { efficiently }\end{array}$ & $\begin{array}{l}\text { In hierarchal model if } \\
\text { at each level the best } \\
\text { approach with respect } \\
\text { to the factor is } \\
\text { applied could yield } \\
\text { better results. Fuzzy } \\
\text { association rules } \\
\text { generation could be } \\
\text { helpful for automated } \\
\text { rules generation }\end{array}$ \\
\hline $\begin{array}{l}{[1} \\
6]\end{array}$ & $\begin{array}{l}\text { Activities } \\
\text { recognition }\end{array}$ & $\begin{array}{l}\text { - Category } \\
\text { assignmentto } \\
\text { incoming } \\
\text { activity } \\
\text { (Association } \\
\text { rules) } \\
\text { - reduces the } \\
\text { false } \\
\text { assignments } \\
\text {-Multi-class } \\
\text { activity } \\
\text { classification }\end{array}$ & $\begin{array}{l}\text { The proposed activity } \\
\text { assigns a category to } \\
\text { the incoming activity, } \\
\text { confidence score of the } \\
\text { assigned category to } \\
\text { reduce false } \\
\text { assignments. A binary } \\
\text { solution is proposed } \\
\text { using SVM, which } \\
\text { simplifies the problem } \\
\text { to correct/incorrect }\end{array}$ & $\begin{array}{l}\text {-Assign a category to the } \\
\text { incoming activity } \\
\text {-Reduces the false } \\
\text { positives in the } \\
\text { assignments } \\
\text {-Multi-class activity } \\
\text { classification }\end{array}$ & $\begin{array}{l}\text { - Activities and sub } \\
\text { activities are } \\
\text { considered } \\
\text { - Quick decision } \\
\text { response }\end{array}$ & $\begin{array}{l}\text { - Prior patterns } \\
\text { needs to } \\
\text { extracted to } \\
\text { identify } \\
\text { abnormal } \\
\text {-Manual rule } \\
\text { based system } \\
\text { for recognizing } \\
\text { discrepancies } \\
\text { Temporal } \\
\text { analysis needs } \\
\text { to be efficient }\end{array}$ & $\begin{array}{l}\text { In hybrid model } \\
\text { Association rules can } \\
\text { be merged with other } \\
\text { classification } \\
\text { techniques such as } \\
\text { ANN for better } \\
\text { results as ANN well } \\
\text { suits for temporal } \\
\text { associations. }\end{array}$ \\
\hline
\end{tabular}

TABLE II. CRITICAL EVALUATION OF RELATED WORK - IMPLEMENTATION AND VALIDATION

\begin{tabular}{|c|c|c|c|c|c|c|c|c|}
\hline $\begin{array}{l}\operatorname{Re} \\
\mathrm{f}\end{array}$ & Dataset & Environment & WSN Size & Types of Sensors & ADL Attributes & $\begin{array}{l}\text { Major } \\
\text { Parameter } \\
\text { improvement }\end{array}$ & $\begin{array}{l}\text { Compared and } \\
\text { Validated against }\end{array}$ & $\begin{array}{l}\text { Implementat } \\
\text { ion } \\
\text { Complexity }\end{array}$ \\
\hline$[15$ & $\begin{array}{l}\text { Dataset } \\
\text { from } \\
\text { "CASAS: A } \\
\text { smart home } \\
\text { in a box." } \\
\text { [10] }\end{array}$ & $\begin{array}{l}4 \text { rooms apartment } \\
\text { with one person in } \\
\text { monitoring }\end{array}$ & 26 sensors & $\begin{array}{l}\text { Motion, } \\
\text { door closure and } \\
\text { temperature (Binary } \\
\text { Sensors) }\end{array}$ & $\begin{array}{l}\text { Bed_to_toilet, Eating, } \\
\text { Enter/Leave_home, } \\
\text { Housekeeping } \\
\text {,Meal_preparation,Relaxin } \\
\text { g, Sleeping, Working }\end{array}$ & $\begin{array}{l}\text { Activity } \\
\text { Recognition } \\
\text { Accuracy } \\
(99.10 \%)\end{array}$ & $\begin{array}{l}\text { Decision Tree } \\
(96 \%), \text { Naïve } \\
\text { Bayesian }(88 \%) \\
\text { and HMM } \\
(95.47 \%)\end{array}$ & Average \\
\hline [5] & $\begin{array}{l}\text { Synthetic } \\
\text { and real } \\
\text { data }\end{array}$ & $\begin{array}{l}\text { LIARA Lab setup } \\
\text { of WSN smart } \\
\text { home. }\end{array}$ & $\begin{array}{l}\text { More than } \\
100 \text { but no } \\
\text { exact } \\
\text { numbers }\end{array}$ & $\begin{array}{l}\text { Binary and numerical } \\
\text { value sensor: } \\
\text { Infrared sensors, } \\
\text { Pressure, electromagnetic } \\
\text { contacts, temperature } \\
\text { sensors, light sensors and } \\
\text { eight RFID antennas }\end{array}$ & $\begin{array}{l}\text { Wake up, Use toilet, } \\
\text { Wash hands, Take shower } \\
\text {, Prepare coffee, Leave } \\
\text { house }\end{array}$ & $\begin{array}{l}\text { Performance } \\
\text { measure: } \\
\text { Execution } \\
\text { time }\end{array}$ & $\begin{array}{l}\text { Not compared } \\
\text { with any existing } \\
\text { approaches }\end{array}$ & Average \\
\hline $\begin{array}{l}{[11} \\
]\end{array}$ & $\begin{array}{l}\text { Synthetic } \\
\text { and real } \\
\text { dataset } \\
\text { [9] }\end{array}$ & $\begin{array}{l}\text { Single elderly } \\
\text { person four } \\
\text { locations are } \\
\text { considered: } \\
\text { Bedroom, toilet, } \\
\text { dining and kitchen }\end{array}$ & $\begin{array}{l}\text { Wearable } \\
\text { sensors } \\
\text { And no } \\
\text { details of } \\
\text { ambient } \\
\text { sensors }\end{array}$ & $\begin{array}{l}\text { Wearable sensors } \\
\text { And no details of ambient } \\
\text { sensors }\end{array}$ & $\begin{array}{l}\text { Resting, Sleeping, } \\
\text { Waking up, Walking, } \\
\text { Eating, Toileting, } \\
\text { Exercise, House hold }\end{array}$ & $\begin{array}{l}\text { Accuracy of } \\
\text { the } \\
\text { abnormality } \\
\text { in daily } \\
\text { routine } \\
(95 \%)\end{array}$ & $\begin{array}{l}\text { Fuzzy } \\
\text { classification } \\
\text { mode }(90 \%) \\
\text { Asthma attack } \\
\text { classification } \\
(93.8 \%) \\
\text { Stress } \\
\text { classification } \\
\text { model }(80 \%)\end{array}$ & $\begin{array}{l}\text { Complex } \\
\text { systems as } \\
\text { multiple } \\
\text { models are } \\
\text { combined } \\
\text { together }\end{array}$ \\
\hline [4] & $\begin{array}{l}\text { Dataset of } \\
\text { SERG } \\
\text { laboratory } \\
\text { at Ulster } \\
\text { University } \\
\text { performed } \\
\text { the } \\
\text { activities } \\
\text { over a } \\
\text { period of } 1 \\
\text { week }\end{array}$ & $\begin{array}{l}\text { A } 27 \text {-year-old man } \\
\text { in the smart home } \\
\text { environment. }\end{array}$ & $\begin{array}{l}\text { No } \\
\text { description } \\
\text { provided }\end{array}$ & $\begin{array}{l}\text { Accelerometer sensors, } \\
\text { light sensor and contact } \\
\text { sensors were utilized }\end{array}$ & $\begin{array}{l}\text { Entering/ Leaving home, } \\
\text { Watching TV, Phone call, } \\
\text { Cooking, Eating, } \\
\text { Drinking, Washing dishes }\end{array}$ & $\begin{array}{l}\text { Identifying } \\
\text { the } \\
\text { uncertainties } \\
\text { w.r.t } \\
\text { precision and } \\
\text { accuracy }\end{array}$ & $\begin{array}{l}\text { Traditional } \\
\text { Activity Model } \\
\text { (TAM) } \\
\text { Generic Activity } \\
\text { Model (GAM) } \\
\text { Semantic Generic } \\
\text { Activity Model } \\
\text { (SGAM) }\end{array}$ & Average \\
\hline [7] & $\begin{array}{l}\text { Dataset } \\
\text { from } \\
\text { "CASAS: A }\end{array}$ & $\begin{array}{l}\text { Datasets represent } \\
\text { sensor data } \\
\text { collected from }\end{array}$ & 26 sensors & $\begin{array}{l}\text { Binary sensors and } \\
\text { temperature sensors }\end{array}$ & $\begin{array}{l}\text { Bathing, Eating, Enter } \\
\text { Home, } \\
\text { Housekeeping, Leave }\end{array}$ & Error rates & $\begin{array}{l}\text { Baseline linear } \\
\text { regression } \\
\text { classification }\end{array}$ & Average \\
\hline
\end{tabular}




\begin{tabular}{|c|c|c|c|c|c|c|c|c|}
\hline & $\begin{array}{l}\text { smart home } \\
\text { in a box." } \\
{[10]}\end{array}$ & $\begin{array}{l}\text { three apartment } \\
\text { testbeds, each } \\
\text { housing has one } \\
\text { older adult }\end{array}$ & & & $\begin{array}{l}\text { Home, Meal Preparation, } \\
\text { Personal Hygiene }\end{array}$ & & $\begin{array}{lc}\text { Win Size } & \text { p-val } \\
1000 & 0.042 \\
2000 & 0.0006 \\
5000 & 0.0059\end{array}$ & \\
\hline$[8]$ & $\begin{array}{l}\text { Physical } \\
\text { implementat } \\
\text { ion }\end{array}$ & $\begin{array}{l}8 \text { weeks Appliance } \\
\text { usage. Ninth and } \\
10 \text { th week } \\
\text { prediction of } \\
\text { appliances usages } \\
\text { are derived and } \\
\text { compared with the } \\
\text { actual durations }\end{array}$ & $\begin{array}{l}\text { Not } \\
\text { discussed ( } \\
\text { communic } \\
\text { ation } \\
\text { standard is } \\
\text { IEEE } \\
802.15 .4)\end{array}$ & $\begin{array}{l}\text { Electrical, Force and } \\
\text { contact(appliance usage), } \\
\text { Flexi force sensors (Data } \\
\text { Acquisition, Activity } \\
\text { Recognition }\end{array}$ & $\begin{array}{l}\text { Sleeping, Dinning, } \\
\text { Watching TV } \\
\text { Relaxing, Toilet }\end{array}$ & $\begin{array}{l}\text { Accuracy in } \\
\text { activity } \\
\text { recognition } \\
\text { and } \\
\text { forecasting } \\
\text { in the given } \\
\text { period of } \\
\text { time }(95 \% \\
\text { improvement } \\
\text { ) }\end{array}$ & $\begin{array}{l}\text { With (Das and } \\
\text { Cook (2005) }\end{array}$ & Complex \\
\hline [9] & $\begin{array}{l}\text { Physical } \\
\text { implementat } \\
\text { ion }\end{array}$ & $\begin{array}{l}\text { Three one- } \\
\text { bedroom single } \\
\text { resident smart } \\
\text { home apartments } \\
\text { for experiments, } \\
\text { referred to as } \\
\text { Apt1, Apt2 and } \\
\text { Apt } 3 \text {. }\end{array}$ & $\begin{array}{l}12 \\
\text { door/cabin } \\
\text { et sensors } \\
\text { Rest of } 20 \\
\text { sensors are } \\
\text { motion } \\
\text { and } \\
\text { temperatur } \\
\text { e sensors }\end{array}$ & $\begin{array}{l}\text { motion sensors, } \\
\text { door closure sensors and } \\
\text { temperature sensors } \\
\text { (Binary Sensors) }\end{array}$ & $\begin{array}{l}\text { Bathing, Eating, Enter } \\
\text { Home, Housekeeping, } \\
\text { Leave Home, Meal } \\
\text { Preparation, Personal } \\
\text { Hygiene, Resting on } \\
\text { Couch, Sleeping in Bed, } \\
\text { Taking Medication }\end{array}$ & $\begin{array}{l}\text { Activity } \\
\text { prediction } \\
(90 \%) \text { and } \\
\text { forecasting }\end{array}$ & $\begin{array}{l}\text { Decision Tree } \\
\text { (DT) (64\%) } \\
\text { Support Vector } \\
\text { Machines (SVMs) } \\
\text { (60\%) } \\
\text { Multi-layer } \\
\text { Perceptron (MLP) } \\
\text { algorithms (62\%) }\end{array}$ & Complex \\
\hline $\begin{array}{l}{[10} \\
]\end{array}$ & $\begin{array}{l}\text { Data set } \\
\text { from } \\
\text { CASAS } \\
\text { smart home } \\
\text { project [10] }\end{array}$ & $\begin{array}{l}\text { Datasets represent } \\
\text { sensor data } \\
\text { collected from } 3 \\
\text { apartment } \\
\text { testbeds, each apt } \\
\text { has one older adult }\end{array}$ & 26 sensors & $\begin{array}{l}\text { Binary Sensors and } \\
\text { temperature sensors }\end{array}$ & $\begin{array}{l}\text { Taking bath , Preparing } \\
\text { breakfast, Listening to } \\
\text { music , Playing game, } \\
\text { Preparing lunch }\end{array}$ & $\begin{array}{l}\text { Activity } \\
\text { recognition } \\
\text { accuracy } \\
\text { (ANN 98\%) }\end{array}$ & $\begin{array}{l}\text { HMM (hidden } \\
\text { Markov model) } \\
(92 \%) \\
\text { NB (Naïve Bayes) } \\
(92 \%) \\
\text { C4.5 }(93 \%)\end{array}$ & Average \\
\hline [2] & $\begin{array}{l}\text { Data set } \\
\text { from [11] }\end{array}$ & $\begin{array}{l}5 \text { residents in } \\
\text { smart home } \\
\text { environment, no } \\
\text { description is } \\
\text { given. }\end{array}$ & $\begin{array}{l}\text { No } \\
\text { description } \\
\text { related to } \\
\text { WSN } \\
\text { implement } \\
\text { ation }\end{array}$ & Binary sensors & $\begin{array}{l}\text { Leaving, Toileting, } \\
\text { Showering, Sleeping, } \\
\text { Breakfast, Lunch, Snack, } \\
\text { Spare time/TV , Grooming }\end{array}$ & $\begin{array}{l}\text { Accuracy of } \\
\text { Activity } \\
\text { recognition } \\
\text { (Hybrid } \\
\text { SVM/HMM } \\
\text { approach) } \\
(68 \%)\end{array}$ & $\begin{array}{l}\text { Hybrid } \\
\text { MLP/HMM } \\
\text { approach }(69 \%) \text {, } \\
\text { HMM }(52 \%) \text {, } \\
\text { SVM }(65 \%)\end{array}$ & Average \\
\hline $\begin{array}{l}{[13} \\
]\end{array}$ & $\begin{array}{l}\text { Datasets } \\
\text { [12] [13] }\end{array}$ & $\begin{array}{l}57 \text { years old } \\
\text { resident in double } \\
\text { story building with } \\
\text { sensors installed in } \\
\text { doors, bed, chair } \\
\text { etc }\end{array}$ & 21 Sensors & $\begin{array}{l}\text { Motion, } \\
\text { door closure and } \\
\text { temperature (Binary } \\
\text { Sensors) }\end{array}$ & $\begin{array}{l}\text { Resting, Sleeping, } \\
\text { Waking up, Walking, } \\
\text { Eating, Toileting, } \\
\text { Exercise, House hold }\end{array}$ & $\begin{array}{l}\text { Activity } \\
\text { identification } \\
\text { accuracy } \\
(61 \%) \text { and } \\
\text { Window } \\
\text { (time slice) } \\
\text { (89\%) for } \\
\text { accuracy } \\
\end{array}$ & $\begin{array}{l}\text { HMM } \\
(\mathrm{A} . \mathrm{ID}=55 \%, \mathrm{~T} . \mathrm{S}= \\
87 \%)\end{array}$ & Average \\
\hline $\begin{array}{l}{[18} \\
]\end{array}$ & Dataset [12] & $\begin{array}{l}\text { Single 26-year-old } \\
\text { male is considered } \\
\text { in three room } \\
\text { Apartments. The } \\
\text { data set consisted } \\
\text { of } 28 \text { days. }\end{array}$ & $\begin{array}{l}14 \text { state- } \\
\text { change } \\
\text { sensors } \\
\text { were } \\
\text { installed } \\
\text { throughout } \\
\text { the } \\
\text { apartment. }\end{array}$ & Binary sensors & $\begin{array}{l}\text { Leave house, Use toilet, } \\
\text { Take shower, Go to bed, } \\
\text { Prepare breakfast, Prepare } \\
\text { dinner, Get drink } \\
\text { Idle }\end{array}$ & $\begin{array}{l}\text { Activity } \\
\text { identification } \\
\text { accuracy ( } \\
81.6,81.6 \\
\text { and } 82.9 \%) \\
\text { are achieved } \\
\text { by three } \\
\text { proposed } \\
\text { algorithms } \\
\text { respectively } \\
\end{array}$ & $\begin{array}{l}\text { Not validated with } \\
\text { any other }\end{array}$ & Average \\
\hline $\begin{array}{l}{[17} \\
]\end{array}$ & $\begin{array}{l}\text { The Domus } \\
\text { Smart home } \\
\text { [14] }\end{array}$ & $\begin{array}{l}\text { Single room } \\
\text { apartment where } \\
\text { each user } \\
\text { performed the } \\
\text { routine ten times, } \\
\text { thus ten sequences } \\
\text { of events to find } \\
\text { frequent patterns }\end{array}$ & $\begin{array}{l}\text { The smart } \\
\text { home } \\
\text { equipped } \\
\text { by } 36 \\
\text { sensors }\end{array}$ & $\begin{array}{l}\text { Binary sensors (IR, } \\
\text { Pressure detector, Lamps, } \\
\text { door contacts, switch } \\
\text { contacts, flow meter }\end{array}$ & $\begin{array}{l}\text { Waking up, Use Toilet, } \\
\text { Preparing Breakfast, } \\
\text { Having Breakfast, } \\
\text { Washing Dishes }\end{array}$ & $\begin{array}{l}\text { Activities } \\
\text { Pattern and } \\
\text { Deviation }\end{array}$ & Not validated & Average \\
\hline $\begin{array}{l}{[14} \\
]\end{array}$ & Data set [9] & $\begin{array}{l}\text { Analysis } \\
\text { conducted on two } \\
\text { humans in separate } \\
4 \text { rooms and } 5 \\
\text { rooms apartments } \\
\text { for } 14 \text { and } 21 \text { days } \\
\text { respectively }\end{array}$ & $\begin{array}{l}12 \text { sensors } \\
\text { (for both } \\
\text { apartments } \\
\text { ) }\end{array}$ & $\begin{array}{l}\text { Binary Sensors } \\
\text { PIR: shower, basin, } \\
\text { cooktop Magnetic: main } \\
\text { door, fridge, cabinet, } \\
\text { cupboard } \\
\text { Flush: toilet } \\
\text { Pressure: seat, bed } \\
\text { electric: microwave, } \\
\text { toaster }\end{array}$ & $\begin{array}{l}\text { Leaving, Toileting, } \\
\text { Showering, Sleeping, } \\
\text { Breakfast, Lunch, Snack/ } \\
\text { SparetimeTV, Grooming }\end{array}$ & $\begin{array}{l}\text { Response } \\
\text { time }(11.3 \\
\mathrm{ms}) \text { and F- } \\
\text { measure } \\
(0.91)\end{array}$ & $\begin{array}{l}\text { Hidden Markov } \\
\text { Model Response } \\
\text { time }(17 \mathrm{~ms}), \mathrm{F}- \\
\text { measure }(0.83)\end{array}$ & Complex \\
\hline
\end{tabular}




\begin{tabular}{|c|c|c|c|c|c|c|c|c|}
\hline$[6]$ & $\begin{array}{l}\text { Data set } \\
\text { (No } \\
\text { information } \\
\text { ) }\end{array}$ & $\begin{array}{l}\text { Five individuals } \\
\text { were asked to } \\
\text { carried out a series } \\
\text { of typical daily } \\
\text { activities. These } \\
\text { activities were } \\
\text { performed in a } \\
\text { house }\end{array}$ & $\begin{array}{l}\text { Multiple } \\
\text { sensors as } \\
\text { RFID }\end{array}$ & RFID & $\begin{array}{l}\text { Brush teeth, Wash face, } \\
\text { Make tea } \\
\text { Wash dishes, Read } \\
\text { newspaper, Read book, } \\
\text { Make curry, Phone call }\end{array}$ & $\begin{array}{l}\text { Activity } \\
\text { recognition } \\
(100 \%) * * *\end{array}$ & Not validated & Complex \\
\hline $\begin{array}{l}{[16} \\
]\end{array}$ & $\begin{array}{l}\text { Nine } \\
\text { datasets }\end{array}$ & $\begin{array}{l}\text { Different datasets } \\
\text { with different } \\
\text { experiment } \\
\text { enviorments }\end{array}$ & Sensors & Different sensors & $\begin{array}{l}\text { Bed_to_toilet, Eating, } \\
\text { Enter/Leave_home, } \\
\text { Housekeeping, } \\
\text { Meal_preparation, } \\
\text { Relaxing, Sleeping, } \\
\text { Working }\end{array}$ & $\begin{array}{l}\text { Precision } \\
(94.57), \\
\text { Recall } \\
\text { (94.57), } \\
\text { Specificity } \\
(90.39), \\
\text { False } \\
\text { Positive Rate } \\
\text { (FPR) } \\
\text { (99.36), } \\
\text { Matthews } \\
\text { Correlation } \\
\text { Coefficient } \\
\text { (0.64) }\end{array}$ & $\begin{array}{l}\text { Different proposed } \\
\text { works }\end{array}$ & Complex \\
\hline
\end{tabular}

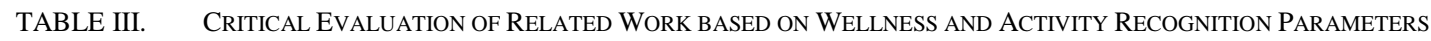

\begin{tabular}{|c|c|c|c|c|c|c|c|c|c|c|}
\hline \multirow{2}{*}{ Ref } & \multicolumn{3}{|c|}{ Type of activity } & \multicolumn{2}{|c|}{$\begin{array}{l}\text { Activities } \\
\text { association }\end{array}$} & \multirow{2}{*}{$\begin{array}{l}\text { Time gap } \\
\text { between } \\
\text { adjacent } \\
\text { activities }\end{array}$} & \multirow{2}{*}{$\begin{array}{l}\text { Activities } \\
\text { time } \\
\text { boundaries }\end{array}$} & \multirow{2}{*}{$\begin{array}{l}\text { Correlation } \\
\text { of activity } \\
\text { and location }\end{array}$} & \multirow{2}{*}{$\begin{array}{l}\text { Temporal } \\
\text { correlation with } \\
\text { the activities }\end{array}$} & \multirow{2}{*}{$\begin{array}{l}\text { Expert } \\
\text { knowledgebase } \\
\text { (Healthcare rules) }\end{array}$} \\
\hline & Simple & Overlapped & Interleaved & Inter & Intra & & & & & \\
\hline [15] & - & $r$ & - & $\checkmark$ & $\checkmark$ & - & - & - & - & $r$ \\
\hline [5] & $r$ & - & - & - & - & $r$ & $\checkmark$ & - & $\checkmark$ & - \\
\hline [11] & $r$ & - & - & - & - & - & - & $\checkmark$ & $r$ & - \\
\hline [7] & $\sqrt{2}$ & - & - & $\checkmark$ & - & - & - & $\checkmark$ & $\checkmark$ & - \\
\hline [8] & $r$ & - & - & $\checkmark$ & - & - & - & $\checkmark$ & $r$ & - \\
\hline [9] & $r$ & - & - & - & - & - & $\checkmark$ & - & $r$ & - \\
\hline$[10]$ & - & $r$ & - & $\checkmark$ & - & - & - & - & $r$ & - \\
\hline [2] & $r$ & - & - & $\checkmark$ & - & - & - & - & $r$ & - \\
\hline [13] & $r$ & - & - & $r$ & $\checkmark$ & - & - & - & $r$ & - \\
\hline [18] & $r$ & - & - & $\checkmark$ & - & - & - & $\checkmark$ & $\checkmark$ & $\checkmark$ \\
\hline [17] & $r$ & - & - & $\checkmark$ & - & - & - & - & $r$ & - \\
\hline [14] & $\checkmark$ & - & - & - & - & - & - & $\checkmark$ & $\checkmark$ & $\checkmark$ \\
\hline [6] & $\checkmark$ & - & - & - & - & - & - & - & - & $\checkmark$ \\
\hline [16] & $\checkmark$ & - & - & - & - & - & - & - & $\checkmark$ & - \\
\hline
\end{tabular}

\section{CONCLUSION}

This study includes literature survey and critical evaluation of existing techniques for wellness detection of elderly people in WSN based smart homes. There are certain vital parameters such as sub activity, location of sub activity, time gap between adjacent sub activities and their temporal associations are identified for the activity detection and wellness detection. Similarly existing literature used different methods for the identification of frequent patterns of elderly people behaviors and finding correlation and association among different parameters. On the basis of the critical evaluation, a model is proposed which is based on association rule mining. The proposed model is based on temporal association of location and sub activities, time gap and temporal association among sequence of sub activities been extracted for the determination of complex activities such as overlapped activities. Association rules and expert knowledge base classifier is proposed for the wellness detection of online data stream from sensor data of smart homes. Learning component is proposed to accommodate the changing trends in the activities pattern of the behavior of the elderly people. In future proposed model will be implemented and tested for 50 elderly people.
Furthermore, result will be compared to existing techniques to evaluate its performance.

\section{REFERENCES}

[1] C. Lindmeier, "“Ageing well” must be a global priority, http://www.who.int/mediacentre/news/releases/2014/lancet-ageingseries/en/," 6 NOVEMBER 2014.

[2] F. J. Ordóñez, P. d. Toledo, and A. Sanchis, "Activity recognition using hybrid generative/discriminative models on home environments using binary sensors," Sensors, vol. 13, pp. 5460-5477, 2013.

[3] Y. Yao, Q. Cao, and A. V. Vasilakos, "EDAL: An energy-efficient, delay-aware, and lifetime-balancing data collection protocol for heterogeneous wireless sensor networks," IEEE/ACM Transactions on Networking, vol. 23, pp. 810-823, 2015.

[4] E. Kim, S. Helal, C. Nugent, and M. Beattie, "Analyzing activity recognition uncertainties in smart home environments," ACM Transactions on Intelligent Systems and Technology (TIST), vol. 6, p. $52,2015$.

[5] M. T. Moutacalli, A. Bouzouane, and B. Bouchard, "The behavioral profiling based on times series forecasting for smart homes assistance," Journal of Ambient Intelligence and Humanized Computing, vol. 6, pp. 647-659, 2015.

[6] L. G. Fahad, A. Khan, and M. Rajarajan, "Activity recognition in smart homes with self verification of assignments," Neurocomputing, vol. 149, pp. 1286-1298, 2015.

[7] B. Minor and D. J. Cook, "Regression tree classification for activity prediction in smart homes," in Proceedings of the 2014 ACM 
International Joint Conference on Pervasive and Ubiquitous Computing: Adjunct Publication, 2014, pp. 441-450.

[8] N. K. Suryadevara, S. C. Mukhopadhyay, R. Wang, and R. Rayudu, "Forecasting the behavior of an elderly using wireless sensors data in a smart home," Engineering Applications of Artificial Intelligence, vol. 26, pp. 2641-2652, 2013.

[9] E. Nazerfard and D. J. Cook, "CRAFFT: an activity prediction model based on Bayesian networks," Journal of Ambient Intelligence and Humanized Computing, vol. 6, pp. 193-205, 2015.

[10] S. T. M. Bourobou and Y. Yoo, "User activity recognition in smart homes using pattern clustering applied to temporal ann algorithm," Sensors, vol. 15, pp. 11953-11971, 2015.

[11] R. M. Forkan, I. Khalil, Z. Tari, S. Foufou, and A. Bouras, "A contextaware approach for long-term behavioural change detection and abnormality prediction in ambient assisted living," Pattern Recognition, vol. 48, pp. 628-641, 2015.

[12] F. J. $\operatorname{Ord} \tilde{\mathrm{A}}^{3} \tilde{\mathrm{A}} \pm \mathrm{ez}, \mathrm{P}$. de Toledo, and A. Sanchis, "Activity recognition using hybrid generative/discriminative models on home environments using binary sensors," Sensors, vol. 13, pp. 5460-5477, 2013.
[13] L. Kalra, X. Zhao, A. J. Soto, and E. Milios, "Detection of daily living activities using a two-stage Markov model," Journal of Ambient Intelligence and Smart Environments, vol. 5, pp. 273-285, 2013.

[14] K. Gayathri, S. Elias, and B. Ravindran, "Hierarchical activity recognition for dementia care using Markov Logic Network," Personal and Ubiquitous Computing, vol. 19, pp. 271-285, 2015.

[15] J. Wen, M. Zhong, and Z. Wang, "Activity recognition with weighted frequent patterns mining in smart environments," Expert Systems with Applications, vol. 42, pp. 6423-6432, 2015.

[16] S. Nasreen, M. A. Azam, U. Naeem, M. A. Ghazanfar, and A. Khalid, "Recognition Framework for Inferring Activities of Daily Living Based on Pattern Mining," Arabian Journal for Science and Engineering, pp. 114, 2016.

[17] J. r. m. Saives, C. m. Pianon, and G. Faraut, "Activity discovery and detection of behavioral deviations of an inhabitant from binary sensors," IEEE Transactions on Automation Science and Engineering, vol. 12, pp. 1211-1224, 2015.

[18] X. Hong and C. D. Nugent, "Segmenting sensor data for activity monitoring in smart environments," Personal and Ubiquitous Computing, vol. 17, pp. 545-559, 2013.

[19] R. Srikant and R. Agrawal, "Mining sequential patterns: Generalizations and performance improvements," in International Conference on Extending Database Technology, 1996, pp. 1-17 